\title{
KNOWLEDGE, ATTITUDES AND PRACTICE IN REGARD TO AIDS: THE CASE OF SOCIAL SCIENCE STUDENTS AT THE UNIVERSITY OF BOPHUTHATSWANA.
}

\author{
HO Kaya and M Kau
}

\begin{abstract}
The necessity of AIDS educational campaigns is to reduce the spread of HIV infection by changing attitudes and practices related to high-risk behaviours. However, before such progranunes are implemented a needs assessment should be conducted. This includes the existing knowledge and attitudes and sexual practices of the specific risk-group. In this study the risk-group were social science students at the University of Bophuthatswana. The majority of the respondents showed a general knowledge about AIDS in terms of its main symptoms, common modes of transmission and the non-availability of a cure. They, however, expressed the need for more information about AIDS. Lack of enough knowledge was shown by their negative attitudes towards those who had already contracted the disease and the number of sexual partners they had. Furthermore, despite the realization of the necessity to use condoms during sexual intercourse, the majority of them did not use them. The study also revealed the minimal role parents, teachers and lecturers play in the dissemination of information about AIDS. The findings call for more AIDS educational programmes to clear away misconceptions about the transmission of the HIV/AIDS virus; and the need to involve parents, schools and universities actively in the dissemination of information about AIDS.
\end{abstract}

\section{OPSOMMING}

Die doel van opvoedkundige VIGS-veldtogte is om die oordraging van die HIV-infeksie te verminder deur houdings en hoërisikoaktiwiteite te verander. Alvorens dit egter kan geskied, moet 'n behoeftebepaling gedoen word, wat onder andere die teikengroep se kennis en houdings, sowel as seksuele aktiwiteite insluit. In hierdie studie is studente in die sosiale wetenskappe van die Universiteit van Bophuthatswana as teikengroep gebruik. Die meerderheid van die teikengroep het 'n algemene kennis oor VIGS gehad, veral ten opsigte van bekende simptome, algemene wyses van oordraging en die feit dat daar tot op hede nog nie 'n geneesmiddel daarvoor vestaan nie. Hulle het egter die behoefte uitgespreek vir meer inligting oor VIGS. 'n Gebrek aan kennis het geblyk uit hulle houding teenoor persone wat reeds VIGS onder lede het, asook die hoeveelheid bedmaats wat hulle gehad het. Ten spyte van die besef oor die noodsaaklikheid vir die gebruik van kondome met seksuele kontak, het die meerderheid glad nie daarvan gebruik gemaak nie. Die studie het ook uitgewys hoe gebrekkig die disseminasie van inligting oor VIGS deur ouers, onderwysers en dosente is. In die lig van die bevindinge word aanbeveel dat daar meer opvoedkundige veldtogte oor VIGS sal plaasvind om wanidees oor die verspreiding van die HIV-virus uit die weg te ruim; en dat ouers, skole en universiteite aktief ingespan moet word in die disseminasie van kennis oor VIGS.

\section{INTRODUCTION}

A decade or more has passed since the discovery of the Human Immunodeficiency Virus (HIV) as the cause of the Acquired Immune Deficiency Syndrome (AIDS).
Inspite of the availability of therapeutic agents that can slow the replication of the virus, there is still neither a cure for AIDS nor a vaccine for HIV infection. The AIDS epidemic has touched all segments of society, both in the industrialized and developing countries including the rich and poor, the young and old, rural and urban people. Thousands of people are either themselves infected with HIV or have lost friends and relatives due to the AIDS disease.

Currently it is known that specific behaviours which include having anal or vaginal sex with an infected person or sharing their IV drug needles and syringes spread the HIV infection. The most important focus of the educational campaigns to reduce the spread of HIV is to change attitudes and practices related with these high risk behaviours. Simbayi and Nombe (1993) emphasized that a health educational campaign can only be effective if it results in changed behaviour. The latter can be accomplished if there are fundamental changes in both the general beliefs and attitudes that people hold concerning any practice. They further argue that before implementing any health education campaign a needs assessment must be conducted. As regards AIDS, there is the necessity to assess the amount of knowledge and attitudes people have about the disease, about those who are already suffering from it and about their existing sexual behavioural practices. Many studies have been carried out in different parts of the world which investigate the amount of knowledge, attitudes towards, and sexual practices related to HIV infection. Such studies have been motivated by the increasing number of people infected with HIV and data obtained from such studies have been useful in helping the development of intervention programmes suitable for specific type of risk-group (Tawanda, 1990).

Most studies have shown that the level of knowledge about AIDS and its modes of transmission vary from country to country and from one social group to another. For instance, studies conducted in developing countries, especially in Africa, indicate that as a result of limited knowledge about AIDS, there are a number of misconceptions about its mechanism of spread. This leads to negative attitudes towards those already infected with HIV. Limited knowledge is a result of low level of literacy and poor quality of information about AIDS disseminated to the public. Concerning sexual practices, the 
studies indicate little or no change in sexual behaviour patterns. This is inspite of the little knowledge people have about the seriousness of the disease (Furley, 1989; Friedman, 1987).

Very few of the existing studies on knowledge and attitudes towards AIDS and related sexual practices carried out in South Africa have been published. Furthermore, most of these investigations were conducted in the Republic of South Africa proper among white sections of society, including students in white universities who live in First World conditions (Bedford, 1992; Van Deventer, 1990). There is, a need for further studies to be carried out in areas such as Bophuthatswana, where the majority of the black South Africans live under Third World conditions.

The objective of this study is to investigate the knowledge, practices and attitudes of students in black universities in South Africa towards the AIDS disease. The University of Bophuthatswana was taken as a case study because it offered convenient and easily accessible samples for the researchers who are both lecturers in social sciences at the relevant campus. University students were selected for the study because studies have indicated that older adolescents and young adults are likely to be sexually active and potential for multiple sex partners and could be a high risk AIDS population group. Moreover, by being better educated than the general public, and mostly single and concerned with sex, they are more attuned to the problem of AIDS, and therefore more likely to change their sexual practices. Social science students were selected because the inter-disciplinary and generalist nature of their studies could make them an important source of AIDS information for other members of society, especially in the rural areas where the majority of them originate.

\section{METIIODOLOGY}

The study involved First and Final Year social science students. The two groups of students were selected in order to investigate whether there was a difference in knowledge and attitudes towards the AIDS disease and sexual practices related to it between those students who have newly arrived at the campus and those who have been there for more than three years. More than 1/3 of both First Year students (87 students) and Final Year students (26 students) participated in the study. Seventy-five per cent of the First Year respondents and $71 \%$ of the Final Year respondents were females. The age range for the First Years was 17 to 33 years. For the Final Yearsit was 21 to 38 years of age. Eighty nine per cent of the First Years and $83 \%$ of the Final Years originated from rural areas of Bophuthatswana and other South African Homelands.

A four page questionnaire containing 23 questions divided into three parts was the instrument used to collect data. The first part provided background biographical data on the respondents such as age, sex, marital status,

place of origin (rural or urban), year of study etc.; the second part was concerned with assessing the general knowledge of the respondents about AIDS and attitudes towards people who were already afflicted with the disease; the third part sought to investigate the respondents' present sexual practices such as the number of sexual partners and attitudes and practices regarding the use of condoms. The questions were both closed and open-ended. A sociology class was used to administer the questionnaire because it is an inter-disciplinary course in which most of the social science students, both first and final years, meet. Participation in the study was voluntary.

The study was descriptive and sought to describe the level of knowledge of, attitudes towards and sexual practices related to AIDS and HIV infection among the social science students.

\section{GENERAL KNOWLEDGE OF THE RESPONDENTS ABOUT AIDS}

All the respondents, both First and Final Years indicated that they had heard about the AIDS disease, although most of them did not know what the letters AIDS or HIV meant. Table 1 below shows the main sources of information about AIDS for the First Year respondents.

\section{Table 1: Main Sources of Information about Aids for First Year Social Science Respondents Total Number of Respondents $(\mathrm{N}=\mathbf{8 7}$ )}

Source of

Information

Radio

Television

Cinema

Printed Media

(Newspapers, Magazines etc.)

Health Workers

Friends

Teachers/Lecturers

Parents

TOTAL

- Total exceeds $100 \%$ because the respondents were allowed to state as many sources of information as possible.

Table 1 indicates that the main sources of information on AIDS for the First year respondents were radio and printed media, followed by friends and television. The majority of the First Year students come from rural areas where television is not the main source of information because rural people may not be able to buy a television set. The Table also reveals the minimal role parents play as sources of information about AIDS. This could be attributed to lack of information on their part about the disease and the influence of tradition whereby parents rarely discuss sexual issues with their children. The most interesting finding concerned the small role teachers and lecturers played as sources of information. Very rarely did they discuss the AIDS problem with the students. The impact of health workers as sources of information about AIDS for the students also seemed very limited in that only $8 \%$ of respondents named heal th workers as sources of information. Table 2 shows the sources of information about AIDS for the Final Year respondents.

\section{Table 2: Sources of Information about Alds/hiv Infection for Final \\ Year Social Science Students \\ Total Number of Respondents $(\mathrm{N}=26)$}

\begin{tabular}{lr}
$\begin{array}{lr}\text { Source of } \\
\text { Information }\end{array}$ & $\begin{array}{r}\% \text { of } \\
\text { Radio }\end{array}$ \\
Television & 62 \\
Cinema & 57 \\
Printed Media & 6 \\
(Newspapers, Magazine etc) & 55 \\
Health Workers & 10 \\
Friends & 32 \\
Teachers/Lecturers & 5 \\
Parents & 2 \\
TOTAL & 229 \\
\multicolumn{2}{l}{ *Total exceeds 100\% because respondents were } \\
allowed to state as many sources of information \\
about AIDS/HIV infection as possible.
\end{tabular}

about AIDS/HIV infection as possible.

Table 2 shows that the main sources of information about AIDS for Final Year respondents were radio, television, printed media and friends. Compared to the First Year respondents, television played an important role for them as a source of information because inspite of their rural background, all had been in Mmabatho, where the University of Bophuthatswana is located for 3 or more years. As in the case of First Year respondents, friends were an important source of information about AIDS for the Final Year respondents and lecturers and parents were a poor source.

As regards the amount of knowledge the two groups of students had about AIDS and HIV infection, the majority of the respondents ( $85 \%$ of First Years and $87 \%$ of the Final Years) knew that AIDS was a condition which had to do with the weakening of the body's immune system. Paradoxically most of them did not know what AIDS and HIV stood for When asked about the causes of AIDS, 56\% of the First Years and $62 \%$ of the Final Years knew that it was due to HIV infection. The rest could not specify the virus causing AIDS. Eighty seven per cent of the First Years and $91 \%$ of the Final Years knew the different modes by which HIV was transmitted. The common modes of transmission stated were sexual intercourse, blood transfusion and sharing unsterilized needles and razors. 
Concerning the country from which AIDS originated, $72 \%$ of the First Years stated Africa, $12 \%$ America, $6 \%$ Europe and the rest did not know or were not sure. In the case of the Final Years, $63 \%$ stated America, $31 \%$ Africa and the rest did not know or were not sure about the origin of the disease. As regards the question whether the original country of the discase was important, $63 \%$ of the First Years and $76 \%$ of the Final Years thought it was not important but $24 \%$ of the First Years and and $20 \%$ of the Final Years said that it was important. The rest were not sure. Forty eight per cent of the First Years and $52 \%$ of the Final Years who indicated that the origin of the disease was not important argued that AIDS was a worldwide problem now, therefore, people should be concerned with fighting it. The rest did not indicate any justification for their position. Those who indicated that the country of origin was important justified their position by the common argument that the source of the disease would give a picture of the extent of its spread to the rest of the world.

When asked to indicate the common symptoms of AIDS the following responses shown in Table 3 were given by the First Year respondents.

\section{Table 3: Common Symptoms of Aids according to First Year Social Science Respondents Total Number of Respondents $(\mathrm{N}=87$ )}

\section{Symptom} $\%$ of Respondents

Loss of Body weight 85

Fatigue 48

Diarrhoea

Swollen Glands in Neck

Skin Rash

Fever

Sores in Armpits,

Mouth, Private Parts etc.

Headache

Loss of Appetite

Vomiting

Mental Illness

TOTAL

* Total exceeds $100 \%$ because each respondent was allowed to list as many symptoms of the AIDS disease as possible.

The majority of the First Year respondents listed loss of body weight as the most common symptom of the AIDS disease, followed by fatigue, swollen glands and neck, skin rash respectively. Table 4 below shows the responses of the Final Year respondents on the same issue of common symptoms for the AIDS disease.
Table 4: Common Symptoms of Aids according to Final Year Social

Science Respondents

Total Number of Respondents $(N=26)$

\begin{tabular}{|lr} 
Symptom & $\%$ of Respondents \\
Loss of Body Weight & 76 \\
Fatique & 52 \\
Swollen Glands in Neck & 45 \\
Diarrhoea & 43 \\
Sores in Armpits, & \\
Mouth, Private Parts etc & 41 \\
Skin Rash & 39 \\
Fever & 31 \\
Loss of Appetite & 23 \\
Coughing & 15 \\
Headache & 13 \\
Hair Loss & 8 \\
Vomiting & 4 \\
Mental Illness & 3 \\
TOTAL & $393^{*}$ \\
*Total exceeds $100 \%$ because the respondents \\
were allowed to list as many symptoms of AlDS as \\
possible.
\end{tabular}

The common symptoms of AIDS, according to the Final Year respondents, were loss of body weight, fatigue, swollen glands and neck, diarrhoea, sores in armpits, mouth, private parts etc. and skin rash respectively. The pattern was almost the same as that indicated by the First Year respondents.

The majority of both First Year $(89 \%)$ and Final Year $(93 \%)$ respondents indicated that there was no cure available for the AIDS disease.Eight per cent $(8 \%)$ of the First Year and $2 \%$ of the Final Year respondents stated that there were traditional ways of curing the disease. The rest of the respondents in both groups either did not know or were unsure.

The study wanted to establish the ideas the respondents had concerning the type of activities or behaviours which present a risk for HIV infection including their attitudes towards those who had contracted the disease. Most First Year (86\%) and Final Year (91\%) respondents indicated the following activities; - casual sex, promiscuity, sharing of unsterilized needles, razors, syringes, toothbrushes; blood transfusion and a pregnant mother with HIV infecting her unborn child. The majority of respondents in both groups knew that HIV cannot be transmitted by casual contact with people around them, witchcraft, kissing, sharing toilets or telephones. Sixty five per cent of the First Year and $55 \%$ of the Final Year respondents, however, were unsure whether the risk of contracting HIV was increased by sharing a bed or eating with someone already suffering from the disease, including the latter's sneezing, coughing and spitting; this uncertainty also applied to insect bites such as those of the mosquito, bed-bug and louse.

Table 5 below shows the responses of the First Year respondents concerning best ways to protect oneself from HIV infection.

Table 5 : Best Ways of Preventing HIV Infection according to First Year Social Science Respondents Total Number of Respondents $(\mathrm{N}=87)$

\section{Ways of}

Prevention

Using Condoms during

Sexual intercourse

Not Sharing Syringes/

Needles/Razors

$\%$ of Respondents

Stick to One Partner

Avoid Casual Sex

Sexual Abstinence

Avoid Kissing

Stay Single

TOTAL

*Total exceeds $100 \%$ because the respondents were allowed to indicate as many ways of HIV prtevention as possible.

\section{Table 6: Best Ways of Preventing HIV Infection according to Final Year Social Science Respondents Total Number of Respondents ( $N=26$ )}

Ways of

Using Comdoms during

Sexual intercours

Stick to One Partner

Avoid Casual Sex

Not Sharing Unsterilized

Syringes/Needles/Razors

Sexual Abstinence

Avoid Kissing

TOTAL

- Total exceeds $100 \%$ because respondents were allowed to list as many ways of HIV prevention as possible.

As these tables show, both First and Final Year respondents indicated very similar ideas about the best ways of protection from HIV.

The respondents were asked the extent to which they feared the disease AIDS. Forty five of the First Year and $48 \%$ of the Final Year respondents were 'very scared'. The rest were either moderately scared, not so scared or did not bother about the disease. This could be attributed to ignorance. This was established by the question "I feel I know very little about AIDS"; $94 \%$ of the First Year and $93 \%$ of the Final Year respondents admitted that they 
knew little about AIDS. The rest were either not sure or thought they knew enough. Moreover, when asked whether AIDS should be discussed in class or not, the majority of them responded positively. This indicated that there was definite need for more information on AIDS.

\section{RESPONDENTS' SEXUAL PRACTICES AND ATTITUDES TOWARDS TIIE USE OF CONDOMS}

Studies on AIDS have suggested that reducing the number of sex partners is one way of lowering the risk of HIV infection but this should take into account the sexual behaviour or the risk level of the partners. This is because the partners will reduce the risk of HIV infection only if they are themselves HIV negative and practice safe sex (Boffey, 1988). The study was, therefore, interested in investigating the number of sexual partners the respondents in both groups of students had before and after knowing something about the AIDS disease. Table 7 below shows the picture for the First Year respondents.

Table 7: The Number of Sexual Partners First Year Social Science Respondents had before and after knowing something about the Aids Disease

Taal Number of Respondents $(\mathrm{N}=87)$

\begin{tabular}{|lrr}
$\begin{array}{lrr}\text { Number of } \\
\text { Sexual Partners }\end{array}$ & \% of Respondents \\
None & Before & Present \\
1 & 8 & 4 \\
2 & 69 & 64 \\
3 & 11 & 21 \\
More than 3 & 8 & 9 \\
TOTAL & 4 & 2 \\
\end{tabular}

Table 7 shows the majority of the First Year respondents had at least one sexual partner before and after knowing something about the AIDS disease. The most alarming notion derived from Table 7 is the number of students $(32 \%)$ who bravely indicated that they had two or more sexual partners even after knowing something about the AIDS disease and the way it spreads rapidly through sexual intercourse. Table 8 shows the situation for the Final Year respondents.

\section{Table 8: The Number of Sexua \\ Partners Final Year Social}

Science Respondents had before and after knowing something about the Aids Disease

Total Number of Respondents $(\mathrm{N}=\mathbf{2 6})$

$\begin{array}{lrr}\begin{array}{l}\text { Number of } \\ \text { Sexual Partners }\end{array} & \text { \% of Respondents } \\ \text { None } & \text { Before } & \text { Present } \\ 1 & 4 & 2 \\ 2 & 83 & 85 \\ 3 & 6 & 8 \\ \text { More than 3 } & 5 & 4 \\ \text { TOTAL } & 2 & 1 \\ \end{array}$

As for the First Year respondents, the majority of the Final Year students had one or more sexual partners before and after knowing something about the AIDS disease. This indicates that sexual behaviour has not changed much. When asked about the precautions which they took to prevent themselves and their partners from HIV infection, the common answers were that either the respondent trusts his/her partner or they trust him/her.

Knowing one's HIV antibody status and that of one's partner is one way of preventing HIV infection and this study was interested in knowing the willingness of the respondents to undergo an HIV antibody test. When asked which was the best way to determine whether or not one has contracted HIV, most respondents in both groups of students indicated that it was through a medical test. More than $60 \%$ of the respondents in each category of the students, however, were not sure whether they should undertake an HIV antibody test. The hesitation was attributed to the social, psychological and economic consequences of the results of the test. There was much concern about the manner in which test resul ts could be taken by relatives, friends, health insurers and other acquaintances. This is supported by studies which have tried to explain the attitude of those who are reluctant to undergo an HIV test. They argue that there are many controversies surrounding HIV antibody testing. Positive tests bring feelings of guilt, anxiety and depression (Macklin, 1988;).

The study also sought to investigate attitudes held by respondents towards condoms and their use. Various studies have indicated that condoms, if used consistently and carefully, are an effective method of reducing the risk of HIV infection; however, research in different countries of the world has shown that the use of condoms is an unpopular strategy among the general public including the youth (Hepworth, 1989).

There are a number of reasons given for this attitude which include association with illicit sex and prostitution, loss of sensitivity for the male during sexual intercourse, vaginal irritation for the female and loss of spontaneity in the sexual encounter. Certain people are against the use of condoms for religious reasons; others fail to use condoms not because they are against them but, because they might not be readily available when they decide to have sex. This is a common situation in the rural areas of most developing countries and especially in Africa. Moreover, others fear breakage, slippage or remaining in the vagina during sexual intercourse (Tanner, 1987).

More than $90 \%$ of the respondents in each category of the students did not use condoms during sexual intercourse. The common reasons given were that it was not necessary since they trust each other and that "condoms dull the beauty of sex". Some expressed that they felt shy to go to a shop and buy condoms either for their own use or that of a partner. They justified their situation by stating that condoms are associated with sex, therefore, buying them publicly might give people a bad impression about the buyer: As regards who should buy condoms, the majority of the respondents in both cases stated that it was a man's responsibility to buy condoms because it was men who put them on during sexual intercourse. When asked whether they preferred having sexual intercourse with a partner wearing a condom or not, the majority of the respondents in both groups thought the condom good for personal safety against pregnancy and sexually transmitted diseases and that it had nothing to do with whether one partner loved the other or not. Those who were against condom use justified their position by arguing that adequate sexual satisfaction during sexual intercourse could not be obtained if condoms were used.

\section{CONCLUSIONS AND RECOMMENDATIONS}

The main findings of the study are summarized as follows:-

First, the majority of the respondents in both groups of students showed a general knowledge about AIDS such and its main symptoms, common modes of transmission, the non-availability of either a western or a traditional medical cure and methods of personal prevention against the disease. The majority of both groups of students, however, admitted that they did not know much about AIDS and they expressed the need for more information about the disease. Lack of sufficient knowledge was shown both by negative attitudes towards those who were HIV positive and the number of sexual partners respondents had even after knowing something about the disease. There is, therefore a need for AIDS educational programmes to clear away some of the misconceptions about the transmission of the virus.

One interesting aspect of the findings was the limited role teachers and lecturers played as 
sources of information about AIDS. There is a great need for teaching staff to be involved actively in the dissemination of AIDS information. This is because students spend a substantial proportion of their time with them. Furthermore, despite their positive attitude towards the necessity of using condoms as protection against HIV infection, the majority of the respondents did not use them during sexual intercourse. Given this discrepancy between attitude and behaviour, safer sex practices, especially the use of condoms need to be highly emphasized in educational programmes.

\section{REFERENCES}

ARNOLD, B. (1989) : Public Knowledge of AIDS. Community Health in New Zealand, 4 (2), 3-15

BEDFORD, R. (1992): AIDS: Knowledge and Attitudes of a group of South African Health Professionals. South African Journal of Psychology, 22(1), 17-20

BETE, C. (1989): AIDS: The Silent Killer, Atlanta, Syndistar.
BOFFEEY, P.M. (1988) : Researchers List Odds of Getting AIDS in Heterosexual Intercourse, New York Times, P. A-1

FRIEDMAN, S.R. (1987): Public Awareness of AIDS and Condoms in Rwanda. Social Science and Medicine, 24 (2), 97-100

FURLEY, K.E. (1989): Public Awareness Survey on AIDS and Condoms in Uganda. AIDS, 3(3) 147-154

HEPWORTH, J. (1989) Strategies for AIDS Education and Prevention. Haworth Press.

IIUNSON, B. (1991): The Complete Guide to Safe Sex, San Fransisco AIDS Foundation

MACKLIN, E.D.(1988): AIDS: Implications for Families. Family Relations, 37, 141-149

SIMBAYI, L.C. AND NOMBE (1993) : A Survey of the Knowledge, Attitudes and Sexual Practices of College of Education Students in Bophuthatswana Regarding AIDS and Condom Use. University of Bophuthatswana (Unpublished Manuscript)
TANNER, W. (1987): The Effect of Condom Use and Sensuous Instruction on Attitudes towards Condoms. Paper presented at the Annual Meeting of the Society for the Scientific Study of Sex, Atlanta, G.A.

VAN DEVENTER, A. (1990) : Community Health in South Africa, University of Orange Free State.

TAWANDA, M. (1990) : Male Knowledge of and Attitudes and Practices Towards AIDS in Zimbabwe. AIDS, 4(3) 245-250

WOLFGANG, F. (1991): Don't be a Casualty of Casual Sex, Aichtal, Magraf Publishers.

\section{H.O. Kaya,}

Department of Sociology, University of Bophuthatswana

M. Kau

Professor, Department of Nursing, University of Bophuthatswana

\title{
CALL FOR PAPERS
}

\author{
The Second International and Interdisciplinary \\ Health Research Symposium \\ "Health Care and Culture" \\ to be held at \\ Lakeview Resort and Conference Centre \\ Morgantown, West Virginia \\ June 14-17, 1995
}

Research and clinical papers, broadly defined, especially those papers emphasizing a cross-cultural perspective in health care, are invited. Submit the following information by 2/1/95: (a) five copies of a 250-300 word abstract without the author's name, (b) a separate page listing the researcher's name, affiliation, address, phone numbers, fax numbers; and (c) four self-addressed and stamped business envelopes. Selected papers will be published in the Symposium Proceedings.

Dr. Wang's first Proceedings received the American Journal of Nursing Book-of-the-Year-Award in "Research" in 1987. We invite you to join us in the challenge of creating a unique Proceedings of excellence.

Send abstracts and/or inquiries by 2/1/95 to: Janet $F$. Wang, $P h D, R N$, Chairperson, Steering Committee, School of Nursing, West Virginia University, P. O. Box 9610, Morgantown, WV 26506. Phone (304) 293-2331, or Fax (304) 293-6826. 